\title{
FLT4 Gene Amplification
}

National Cancer Institute

\section{Source}

National Cancer Institute. FLT4 Gene Amplification. NCI Thesaurus. Code C129618.

A molecular genetic abnormality indicating the presence of multiple copies of the FLT4 gene. 